Ewa Szóstak

\title{
CREATING PUBLIC AID MODEL IN POLAND
}

The term public aid is relatively new in Poland and was brought to life due to a need for adjusting to the Community law. The first bill, dated on June 30, 2000. concerning limit conditions and controlling public aid for contractors took effect on January 1, 2001..$^{1}$ It stated who is eligible to benefit from and provide public aid. Soon, however, this bill was replaced with a new one dated on July 27, 2002 determining limit conditions and controlling public aid for contractors ${ }^{2}$. Since January 1, 2007 new de minimis regulations have been in force (European Commission regulation in force to the end of 2013).

Most important changes concern increasing the limit of public aid up to 200.000 euros granted within 3 years without the necessity of reporting it to the European Commission. The regulation also concerns traffic transport sector which was included to de minimis aid. However, in this case, maximum aid limit cannot exceed 100.000 euros and must not be used to purchase vehicles.

The regulation also concerns processing agricultural products as well as bringing them into circulation, which so for was regulated separately.

Apart from the minimis aid one should also consider other regulations bringing changes for horizontal and regional aid such as:

- European Commission guidelines for domestic regional aid within 2007$2013^{3}$,

- European Commission regulation № 1628/2006 for using investment regional aid ${ }^{4}$,

- guidelines concerning state help to support small business in the access to venture capital ${ }^{5}$,

Dz. U. z 2000 r., Nr 60, poz. 704

Dz. U. z 2002 r., Nr 141, poz. 1171 ze zm.

Dz. Urz. UE z 04.03.2006, C 54/13

Dz. Urz. UE z 01.11.2006, L 302/29

Dz. Urz. UE z 18.08.2006, C 194/2 
- guidelines for a state to support research and development ${ }^{6}$,

- guidelines for a state to support agricultural and forest sectors within 2007$2013^{7}$.

Public aid procedures for Polish contactors (?) have changed since Poland joined the European Union. Now Poland is to obey European regulations and decrees, the European Court of Justice (ECJ) and a court of first instance. What is more, the European Union law is superior to domestic regulations in case it comes to contentions issues ${ }^{8}$.

Public aid is a legal issue as well as economic and public finances. Therefore, granting public aid is directly connected with the following problems:

- competition protection;

- using public aid effectively as an economic policy instrument;

- using public means to finance public aid effectively including European Union funds.

The application of the European Union public aid law in practice means to control granting a contractor, which brings to competition protection. The basis of granting public aid is domestic law regulations, which, within European law margin, determine the execution of economic aims using public aid most effectively.

The problem of granting allowance to a contractor was regulated by the tax law of August 29, 1997 . There are some types of using allowances by a tax body. The first type concerns tax allowance that is not treated as a public aid. It is granted because of the importance of the taxpayer's interest or public interest.

The second type deals with granting tax allowance within "de minimis aid". The third type deals with granting allowances that are controlled by and included in European Union regulations.

The main aim of this article concerns domestic and EU regulations for public aid. What is characteristic of these regulations, especially at the European community level, is their dynamism. They often change, which is caused by public aid policy reforms. Therefore, some issues of this paper are focused on public aid institutions and problems that may occur while proceeding and monitoring the above-mentioned aid.

In a word, the study focuses on:

Dz. Urz. UE z 30.12.2006, C 323/1

Dz. Urz. UE z 27.12.2006, C 319/1

Dz. U. z 1997 r., Nr 78, poz. 483 ze zm.

Dz. U. z 2005 r. Nr 8, poz. 60 ze zm. 
1. rules of permitting public aid;

2. types of public aim
a) de minimis aid,
b) types of horizontal aid,
c) sector aid.

A paradox in the European Union law is that it is not possible to find a definition of public aid there. It may not have been included on purpose, to avoid a situation in which EU countries would evade the regulations. On the other hand, the existance of such a definition would enable the European Commission and the ECJ to interpret the term in too flexible a way. That is why estabilishing the European Community definition banned granting public aid. According to this regulation any state help is against the common market as it may privilege some companies or some production sectors simultaneously ruining competition.

What may be concluded out of the aforesaid idea is that either public or state aid brings financial benefits to a particular contractor. And nothing is wrong about this fact as long as the following conditions are not fulfilled:

1. it comes directly from public financial means (e.g. writing off an estate tax that makes commune budget income). State aid may be granted by administrative organ (at the national, regional and local level) and public or private organs that have been granted the right to manage and control public financial means;

2. a contractor benefits because of a better price than a free market price (e.g. a contractor rents a real estate that is owned by a commune at a lower price than a market price);

3. is a selective kind, which means that makes some contractors or some goods production privileged (e.g. writing off a real estate tax in case of protected working place);

4. endangers competition and influences trade exchange among EU countries.

The European Union wants the idea of equal chances for all contractors to function in real world. Otherwise, some of them take advantages over their contracting parties. Still, the rule of disagreement does not mean "no public aid grant". European Community law characterizes some spheres, aims and types of help which can be granted after meeting certain requirements.

There are two exceptions to the aforesaid rule, namely:

1. authomatic aid, which means legally acceptable with common market rules: 
a) social aid for individual consumers on condition that it does not discriminate the origin of product;

b) aid granted to eliminate damages caused by natural disasters or other unexpected situations.

In both cases the contractor cannot benefit more than social and only social aid in the first case and just reconstructing damages in the second one;

2. conditional aid, which requires estimation from the European Commission. This case concerns conditional exemption of "no public aid grant" as a way to disturb competition and influencing trade exchange among European Union countries. In return one may get help classified in the following categories:

a) regional help,

b) horizontal help,

c) sector help.

European Commission distinguishes such kinds of public aid:

- subsidy;

- bank credit interest excess;

- reimbursement;

- writing off a tax;

- tax deduction;

- base tax decrease or tax fee decrease;

- other expenses connected with budget departments functioning or following their statute tasks;

- payment exemption;

- giving up charging a tax;

- giving up charging a payment;

- writing off tax arrears along with interests;

- writing off interests on tax arrears;

- writing off payment and interests on payments;

- writing off financial penalties;

- giving to a contractor properties owned by the treasury or local government at more profitable conditions than market ones; 
- selling off the treasury or local government properties at more profitable conditions than market ones;

- capital contribution to a campany receivables conversation to stocks and shares,

- preference loans;

- loans written off conditionally or financial punishment;

- making one pay tax arrears on the installment plan.

Regardless of the sort of public aid, gross or net, subsidy equivalent needs to be calculated in order to state the sum to be granted.

The gross subsidy equivalent is the amount of money that one may be granted as a subsidy without taking income tax into account in contrast to the net subsidy equivalent when income tax is taken into account. The ways to calculate gross and net subsidy equivalents are stated in the Cabinet decree dated on August 11, 2004 ${ }^{10}$.

According to the regulation of the Commission nr 1998/2006 dated on December 15, 2006 concerning de minimis state aid $^{11}$, an entity applying for such an aid is obliged to present an application form as well as all the documents proving de minimis financial subsidy granted within three years ${ }^{12}$.

The entity of state aid is a contractor who, according to the bill dated on July $2,2004^{13}$, is a private person or a legal person running a business. The aforesaid bill also defines the term "running a business", or in other words, economic activity: it is a paid commercial manufacturing, building or service activity and a mining industry and also a professional activity performed in an organized and permanent way.

According to the rules of competiton policy public financial aid may be granted most of all to small and mean contractors. Apart from that a new definition for a microcontractor was introduced. And the term describes a contractor who within last two years:

1. hired not more than 10 workers and,

2. reached a net turnover not higher than 2 million euros.

A small contractor is the one who within last years:

1. hired not more than 50 workers and,

2. reached a net turnover not higher than 10 million euros.

Dz. U. z 2004 r. Nr 194, poz. 1983

Dz. Urz. UE z 28.12.2006, L 379/5

Dz. U. z 2004 r., Nr 123, poz. 1291 ze zm.

Dz. U. z 2004 r., Nr 173, poz. 1807 ze zm. 
A mean contractor is the one who within last years:

1. hired not more than 250 workers and,

2. reached a net turnover not higher than 50 million euros.

Horizontal help is divided into:

a) one used to keep workplaces or creating new ones (European Community regulation no 1976/2006 dated on December 20, 2006 dealing with a workplace state aid) ${ }^{14}$;

b) one used for environmental protection ${ }^{15}$;

c) restructuring aid ${ }^{16}$;

d) one used for research and development activity ${ }^{17}$;

e) one used to support small and medium companies ${ }^{18}$;

f) ones used for professional training.

Sector aid is regulated by the European Union law and divided into particular sectors:

b) postal,

c) public media (radio and television),

d) audiovisual,

e) coal mining industry,

f) synthetic fibres,

g) ship building industry,

h) steel and iron industry,

i) moto industry,

j) electropower industry. 


\section{Streszczenie}

Obecnie prawo Unii Europejskiej stanowi podstawę dla udzielania pomocy publicznej. Przepisy polskiej ustawy dotyczą jedynie kontroli procedur jej przyznawania i koordynacji działań właściwych organów, mianowicie prezesa Urzędu Ochrony Konkurencji i Konsumentów oraz organów UE.

Stały szybki rozwój Polski powoduje, że środki publiczne powinny być wydawane w sposób jak najbardziej efektywny, co oznacza, że nie mogą być wykorzystane do krótkoterminowych politycznych celów albo być przeznaczone na cele socjalne lub lokalne.

Co więcej, pomoc finansowa przyznana przedsiębiorstwom powinna stymulować rozwój technologiczny i ekonomiczny. Jak również - co wydaje się oczywistym - powinna być związana ze stałą długookresową polityką ekonomiczną. 